\title{
ALLERGENS FROM FUSARIUM SOLANI IDENTIFIED BY IMMUNOBLOTTING IN ASTHMA PATIENTS IN IRAN
}

\author{
Ali Reza KHOSRAVI ${ }^{1}$, Mahnaz FATAHINIA ${ }^{1}$, Hojjatollah SHOKRI ${ }^{2}$, and \\ Mohammad Hossein YADEGARI ${ }^{3}$ \\ Mycology Research Center, Faculty of Veterinary Medicine, University of Tehran, Tehran ${ }^{1}$, Faculty of Veterinary \\ Medicine, University of Mazandaran, Amol ${ }^{2}$, Department of Mycology, Faculty of Medicine, University of Tarbiat \\ Modares, Tehran ${ }^{3}$, Iran
}

\begin{abstract}
We extracted Fusarium solani antigens to evaluate specific anti-F. solani IgE in fifty-one patients with asthma ( 33 men and 18 women) and in 22 non-atopic healthy subjects (15 men and 7 women). F. solani strains were cultured in Sabouraud glucose agar and subjected to cell disruption using the freeze-and-thaw method. The obtained cytoplasmic extracts were analysed using sodium dodecyl sulphate-polyacrylamide gel electrophoresis (SDS-PAGE). Sensitisation to F. solani antigens has been evaluated in asthmatic patients using the immunoblotting assay. The SDS-PAGE identified 29 protein bands in the cytoplasmic extracts of $F$. solani isolates, with molecular weights ranging from $24 \mathrm{kDa}$ to $112 \mathrm{kDa}$. Immunoblotting detected specific anti-F. solani IgE antibody in all asthma patients, but not in the control group. The predominant reactive allergens in patients corresponded to the bands with molecular weights of $24 \mathrm{kDa}, 58.5 \mathrm{kDa}$, $64.5 \mathrm{kDa}, 69 \mathrm{kDa}, 72 \mathrm{kDa}$, and $97 \mathrm{kDa}$. Our results suggest that various allergenic components of $F$. solani may produce symptoms of asthma in susceptible individuals and they call for further research.
\end{abstract}

KEY WORDS: airborne spores, allergenic sensitisation, fungal allergy, IgE, SDS-PAGE

Today, more than one fifth of the world population faces IgE-mediated allergic diseases such as asthma, rhino-conjunctivitis, and eczema (1). Asthma is a complex illness resulting from an interplay of several allergenic and non-allergenic factors, and is characterised by airway obstruction and inflammation (2).

Sensitisation to allergens has an important role in the development of asthma (3). Fungal spores and mycelia are well known respiratory allergens. It is estimated that $3 \%$ to $40 \%$ of allergic patients worldwide suffer from fungal allergy (4). By now, the role of fungi in the development of asthma has not been fully investigated. Alternaria alternata, Aspergillus fumigatus, and Cladosporium herbarum have been reported as the most common causes of fungal allergies, and many allergens of these fungi have been described at the molecular level $(5,6)$. In addition, airborne spores of the Fusarium species are also widely dispersed and common in many environments $(7,8)$. These saprophytic or parasitic fungi often contaminate crops, fruit, and vegetables. They also frequently affect the eyes, skin and nails, and cause systemic infections in immunocompromised hosts $(9,10)$. Among the Fusarium species, F. solani plays the most important role in IgE-mediated allergic reaction in patients with nasobronchial allergy (11). O'Neil et al. (12) found that about $24 \%$ of atopic individuals had the skin test and radioallergosorbent test positive to $F$. solani extracts.

The culture filtrate, mycelium, and spore extracts of $F$. solani contain various allergens, either speciesspecific such as the 65-kDa glycoprotein (13) or shared with related species or genera. 
The diagnosis of allergy is usually based on the medical history of the patient, skin prick tests, and in vitro tests for allergen-specific $\operatorname{IgE}$ in the patient serum. However, most commercial fungal allergen extracts used for in vivo and in vitro diagnostics are neither pure enough nor standardised. Our study is an attempt to investigate potential allergenic proteins from $F$. solani that could improve screening for asthmatic patients by widening the array of known fungal allergens.

\section{MATERIALS AND METHODS}

\section{Chemicals and reagents}

All general chemicals and reagents used in the study were purchased from Merck Co. (Darmstadt, Germany), unless specified otherwise.

\section{Strain and cultivation}

A total of 12 F. solani strains were isolated from the air and foodstuffs from Iran. First the samples were cultured in Sabouraud glucose agar supplemented with $0.5 \%$ chloramphenicol (Sigma Chemical Co., St. Louis, Mo., USA) at $30{ }^{\circ} \mathrm{C}$ for 5 days. All Fusarium $\mathrm{sp}$. isolates were further subcultured on potato dextrose agar (PDA), Spezieller Nährstoffarmer agar (SNA), and carnation leaf agar (CLA). PDA cultures were incubated at $30^{\circ} \mathrm{C}$ for 5 to 7 days, while CLA and SNA cultures were incubated at $25^{\circ} \mathrm{C}$ for 2 to 4 weeks.

The cultures were evaluated both by eye and microscopically. For morphological identification of the isolates we followed the criteria of Leslie and Summerell (14). Colony morphology was observed from cultures cultivated on PDA. To assess the morphology of macroconidia, microconidia, conidiogenous cells, and the chlamydospores we used the cultures incubated on SNA and CLA.

\section{Cell fractionation and crude extract preparation}

The fungal colonies were cultured in $500 \mathrm{~mL}$ of Sabouraud glucose broth and agitated in the shaker at $30{ }^{\circ} \mathrm{C}$ for 10 days. At the end of incubation, the fungal mats of each strain containing spores and mycelia were harvested using the filtration technique (Whatmann filter paper; no. $0.45 \mu \mathrm{m}$ ) and washed three times with the PBS buffer $\left(0.15 \mathrm{~mol} \mathrm{~L}^{-1}, \mathrm{pH}\right.$ 7.2). A suspension of wet fungal colonies was prepared in a lysing buffer
(62.5 $\mathrm{mmol} \mathrm{L}^{-1}$ Tris, $1 \mathrm{mmol} \mathrm{\textrm {L } ^ { - 1 }}$ dithiothreitol, $0.2 \mathrm{mg} \mathrm{mL}^{-1}$ of phenyl sulfonyl fluoride and $15 \%$ glycerol, $\mathrm{pH}$ 6.8). Cells were disrupted by freezing them to $-70{ }^{\circ} \mathrm{C}$ for $30 \mathrm{~min}$ and thawing them over 20-minute intervals, repeating the procedure six times in a row (the so called freeze-and-thaw method). The samples were finally ground by a sterilised mortar for $20 \mathrm{~min}$. Crude antigens were separated from other cell components by centrifugation at $20000 \mathrm{~g}$ for $20 \mathrm{~min}$, and subsequently centrifuged at $25000 \mathrm{~g}$ for $30 \mathrm{~min}$. Clear supernatants were obtained and stored at $-20{ }^{\circ} \mathrm{C}$ until used.

\section{Protein determination}

Protein concentration of fungal extracts was measured after reconstituting the extracts in $50 \mu \mathrm{L}$ and $100 \mu \mathrm{L}$ of distilled water using the Bradford method (15).

\section{SDS-PAGE analysis}

To separate the fungal extracts we used a $17.5 \%$ separation gel with a $5 \%$ stacking gel in a discontinuous buffer system as proposed by Laemmli (16). The extracts were boiled in a reducing sample buffer with 2 - $\beta$-mercaptoethanol for $5 \mathrm{~min}$. Aliquots of the sample ( $\mathrm{V}=10 \mu \mathrm{L}$, which equals to $60 \mu \mathrm{g}$ of proteins) were loaded on a $0.5 \mathrm{~cm}$ gel. Molecular weight standard markers of $14.4 \mathrm{kDa}$ to $93 \mathrm{kDa}$ (Rainbow markers, Amersham International PLC, UK) were also loaded on the gel. The gels were stained with silver nitrate and commassie brilliant blue R-250 (Sigma, St. Louis, USA).

\section{Serum collection}

Sera used in this study were pooled from 51 adult patients (33 men and 18 women aged 20 to 60 years) whose asthma had been confirmed by a physician. The majority $(62.7 \%)$ were younger than 40 years. They were recruited in the Tehran Allergy Clinic, Iran. The sera were also taken for testing from an age and sex matching control population of 22 healthy subjects (15 men and 7 women) with no personal or family history of atopy. All subjects gave informed consent to participate in the study.

All underwent a detailed clinical examination with special attention to the respiratory system. All subjects also completed a questionnaire with personal data and information related to possible confounding factors such as smoking, drugs used, history of diseases, respiratory and non-respiratory allergic symptoms, 
history of oral corticosteroid use and other therapies. All patients had a history of bronchitis, difficulties breathing, and limited lung capacity. None took any kind of medications. Only five patients smoked.

Blood was collected by venipuncture in BD vacutainers (Becton Dickinson, UK) and allowed to clot to facilitate serum collection. Sera collected from each subject were pooled into one sample for each study group, frozen, and stored until use.

Serum IgE against $F$. solani antigens was determined using the immunoblotting assay.

\section{IgE immunoblotting}

The isolated Fusarium sp. proteins were transferred to nitrocellulose sheets (Schleicher and Shuell, Dassel, Germany) with a transphor apparatus (Hoefer, San Francisco, USA) at $100 \mathrm{~V}$ for $2.5 \mathrm{~h}$ using a transfer buffer ( $25 \mathrm{mmol} \mathrm{L}^{-1}$ Tris, $192 \mathrm{mmol} \mathrm{L}^{-1}$ glycin, $0.03 \%$ SDS, and $20 \%$ methanol, $\mathrm{pH} 8.3$ ). The nitrocellulose sheets were cut into $0.5 \mathrm{~cm}$ strips and incubated overnight at $4{ }^{\circ} \mathrm{C}$ with the TBS-Tween 20-BSA buffer $\left(20 \mathrm{mmol} \mathrm{L}^{-1}\right.$ Tris, $0.15 \mathrm{~mol} \mathrm{~L}^{-1} \mathrm{NaCl}, 0.05 \%$ Tween 20 , and $1.5 \% \mathrm{BSA}, \mathrm{pH} 7.5$ ). The strips were washed three times with the TBS-Tween 20 buffer at room temperature for $15 \mathrm{~min}$.

Pooled serum was diluted to 1:2 in TBS-Tween 20-BSA and incubated at room temperature for $16 \mathrm{~h}$. After the strips had been washed three times with TBSTween 20-BSA, each was added anti-human IgE conjugated with alkaline phosphatase (Sigma, St. Louis, USA) diluted to 1:1000 in TBS-Tween 20-BSA. The strips were then incubated for $5 \mathrm{~h}$ and then washed in the alkaline phosphatase buffer $\left(100 \mathrm{mmol} \mathrm{L}^{-1}\right.$ Tris$\mathrm{HCl}, 100 \mathrm{mmol} \mathrm{L}^{-1} \mathrm{NaCl}$, and $5 \mathrm{mmol} \mathrm{L}^{-1}$ magnesium chloride) for $10 \mathrm{~min}$. The immunoblot with at least one visible protein band was considered positive (17).

\section{RESULTS}

The SDS-PAGE electrophoregram obtained from cytoplasmic extracts of $F$. solani isolates has shown 29 protein bands with molecular weights ranging from $24 \mathrm{kDa}$ to $112 \mathrm{kDa}$ (Table 1 and Figure 1). The gel showed a moderate degree of similarity between the protein banding patterns of various fungal isolates. Overall, the isolates differed in 27 bands whereas two bands were common in all isolates. The most common protein bands were $24 \mathrm{kDa}$ and $32 \mathrm{kDa}$, followed by $72 \mathrm{kDa}$ and $50 \mathrm{kDa}$, whereas bands with molecular weights of $108 \mathrm{kDa}, 87 \mathrm{kDa}$ and $40 \mathrm{kDa}$ were the least common bands within the $F$. solani isolates.

As isolates 1, 4, 8, and 12 had the highest number of protein bands, they were selected for immunoblotting to detect the presence of IgE against $F$. solani antigens. Immunoblotting of the pooled sera of the asthmatic patients showed a strong reaction to fungal extracts. At the same time, no positive result was observed in controls. IgE responded to 29 different bands in asthmatic patients (Figure 2). The strongest response was to the following six allergens: $24 \mathrm{kDa}, 58.5 \mathrm{kDa}$, $64.5 \mathrm{kDa}, 69 \mathrm{kDa}, 72 \mathrm{kDa}$, and $97 \mathrm{kDa}$.

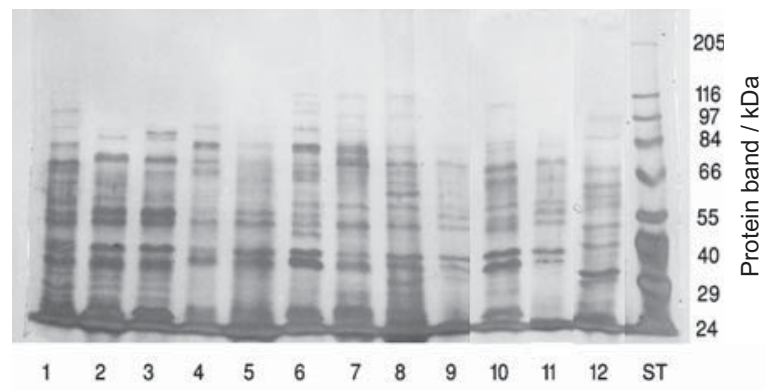

Figure 1 Protein components of crude extracts of Fusarium solani isolated with SDS-PAGE.

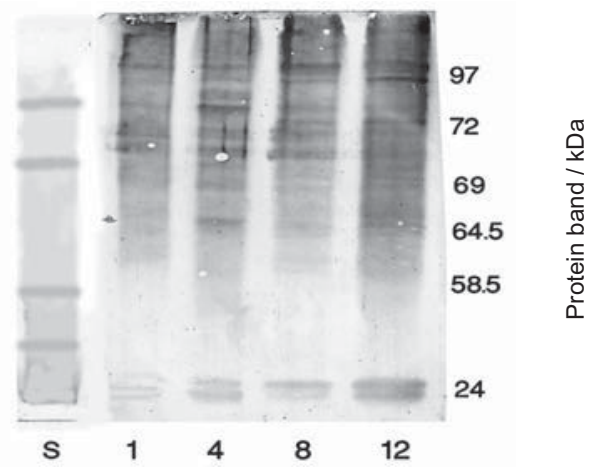

Figure $2 \operatorname{IgE}$ binding to Fusarium solani allergen extracts in the immunoblotting test with pooled serum of 51 patients with asthma.

\section{DISCUSSION}

Members of the genus Fusarium are common indoor and outdoor airborne fungi, confirmed to cause bronchial asthma (18). Earlier studies $(19,20)$ suggest that sensitivity to fungi is common, especially in patients with asthma.

Polyacrylamide gel electrophoresis is frequently used to isolate and identify proteins from different fungal species (21). The same method was successfully employed in the present study. The most important finding is that $F$. solani isolates showed several similar 
Table 1 Bands identified with the SDS-PAGE in each of the 12 isolates of Fusarium solani.

\begin{tabular}{clc}
\hline Isolate No. & \multicolumn{1}{c}{ Protein bands $/ \mathbf{k D a}$} & Total number of bands \\
\hline 1 & $24,26,27,32,38,45,55,58.5,64,69,72,81,94,100$ & 14 \\
\hline 2 & $24,26,28.5,32,37,50,55,60,63,72,81$ & 11 \\
\hline 3 & $24,26,28.5,32,37,50,53,60,66,72,87$ & 13 \\
\hline 4 & $24,32,35,40,50,53,58.5,66,72,81,94,100,112$ & 8 \\
\hline 5 & $24,32,35,50,53,64,72,81$ & 8 \\
\hline 6 & $24,32,35,61,64,66,72,81$ & 9 \\
\hline 7 & $24,28.5,32,35,50,58.5,75,81,97$ & 13 \\
\hline 8 & $24,28.5,32,35,50,58.5,61,64,69,72,81$ & 6 \\
\hline 9 & $24,32,35,50,53,75$ & 10 \\
\hline 10 & $24,27,32,38,45,55,63,66,81,108$ & 8 \\
\hline 11 & $24,28,32,38,45,55,63,66$ & 10 \\
\hline
\end{tabular}

protein profiles in cytoplasmic extracts within the range of $24 \mathrm{kDa}$ to $112 \mathrm{kDa}$. In a previous study by Aghamirian and Zaini (22), somatic proteins UAMH 3317 and UAMH 7419 extracted from $F$. solani produced 16 and 21 protein bands, respectively, with molecular weights of $14 \mathrm{kDa}$ to $100 \mathrm{kDa}$. In a cytoplasmic extract of $F$. solani isolated from the soil, Bahrain Mandeel et al. (23) identified 18 protein bands ranging from $21 \mathrm{kDa}$ to $100 \mathrm{kDa}$. In addition, using the SDS-PAGE method, Verma and Gangal (24) demonstrated 18 cytoplasmic protein bands from $F$. solani in India, with the $65-\mathrm{kD}$ protein component as a major allergen. It is difficult to identify a protein in a complex antigen extract on the basis of its molecular weight, and sometimes the same antigen differs in molecular weight between studies. This discrepancy may be related to differences in the calculation of molecular weight, differences in medium composition and incubation temperature or to the presence of several antigens with the same molecular weight (25). Investigation should be continued to further specify the bands.

For clinical diagnosis it is essential to identify the allergenic profiles of the Fusarium species, F. solani in particular, and see if there are any IgE-cross reactivities between major allergens of this widespread fungus. Immunoblotting is a readily available and simple screening test for IgE binding to major $F$. solani allergens. In this study, we identified six major allergens of $F$. solani with molecular weights of $24 \mathrm{kDa}, 58.5 \mathrm{kDa}, 64.5 \mathrm{kDa}, 69 \mathrm{kDa}, 72 \mathrm{kDa}$, and $97 \mathrm{kDa}$. In two studies conducted by Verma et al. (11, 26), a $65-\mathrm{kDa}$ allergen of $F$. solani bound IgE from all the sera of asthmatic patients. Verma et al. (27) also demonstrated that peptide named IV-1, a 3.4-kDa fragment of the $65-\mathrm{kDa}$ allergen, was highly allergenic and bound to $\operatorname{IgE}$ in the sera of most $F$. solani-positive patients. In another study (28), the same researchers found that a $45-\mathrm{kDa}$ allergen of $F$. solani reacted with patients' sera sensitive to many fungi.

In general, IgE response seems to vary from country to country. Our results disagree with the findings of O'Neil et al. (12) and Hoff et al. (29), who established IgE response to extracts of Fusarium species in $24 \%$ and $50 \%$ of atopic patients from the USA and Germany, respectively. The reasons for these differences are not clear, but point to differences in exposure between these countries that may involve climate/geography, Fusarium strains, heating, ventilation, and air-conditioning. In addition, the study procedures may have varied, including the allergen extraction methods, patient recruitment criteria, and assays used. Furthermore, immune responses to the allergens may vary between different populations and even races (30), as allergies result from an interplay of various environmental and genetic factors. Nevertheless, this discrepancy between our and the reported studies needs further clarification.

In conclusion, we identified six allergenic bands of $F$. solani (corresponded to $24 \mathrm{kDa}, 58.5 \mathrm{kDa}$, $64.5 \mathrm{kDa}, 69 \mathrm{kDa}, 72 \mathrm{kDa}$ and $97 \mathrm{kDa}$ proteins), which showed the highest IgE-binding frequency in asthmatic patients. These results suggest that different allergenic components of $F$. solani may produce symptoms of asthma in susceptible individuals and call for further investigation. 


\section{Acknowledgement}

This study was funded by the Mycology Research Center, Faculty of Veterinary Medicine, University of Tehran, Iran.

\section{REFERENCES}

1. Johansson SGO, Haahtela T. World allergy organization guidelines for prevention of allergy and allergic asthma. Int Arch Allergy Immunol 2004;135:83-92.

2. Yssel H, Abbal C, Pène J, Bousquet J. The role of IgE in asthma. Clin Exp Allergy 1998;28(Suppl 5):104-9.

3. Bierman CW, Pearlman DS, Shapiro GG, Busse WW. Allergy, asthma and immunology from infancy to adulthood. 3rd ed. Pennsylvania: WB Suanders Company; 1988.

4. Horner WE, Helbling A, Salvaggio JE, Lehrer SB. Fungal allergens. Clin Microbiol Rev 1995;8:161-79.

5. Black PN, Udy AA, Brodie SM. Sensitivity to fungal allergens is a risk factor for life-threatening asthma. Allergy 2000;55:501-4.

6. Crameri R. Molecular cloning of Aspergillus fumigatus allergens and their role in allergic bronchopulmonary aspergillosis. Chem Immunol 2002;81:73-93.

7. Shokri H, Khosravi AR, Naseri A, Ghiasi M, Ziapour SP Common environmental allergenic fungi causing respiratory allergy in Northern Iran. Int J Vet Res 2010;4:169-72.

8. von Wahl PG, Kersten W. Fusarium and Didymella-neglected spores in the air. Aerobiologia 1991;7:111-7.

9. Nucci M, Anaissie E. Fusarium infections in immunocompromised patients. Clin Microbiol Rev 2007;20:695-704.

10. Sharma OP. Deuteromycetonia Fusarium. In: Sharma OP, editor. Textbook of fungi. New Delhi: Tara McGraw-Hill; 1989. p. 26-71.

11. Verma J, Gangal SV. Studies on Fusarium solani: cross reactivity among Fusarium species. Allergy 1994;49:3306.

12. O'Neil CE, McCants mL, Salvaggio JE, Lehrer SB. Fusarium solani: prevalence of skin reactivity and antigenic allergenic analysis. J Allergy Clin Immunol 1986;77:842-9.

13. Verma J, Sridhara S, Singh BP, Gangal SV. Studies on shared antigenic/allergenic components among fungi. Allergy 1995;50:811-6.

14. Leslie JF, Summerell BA. The Fusarium Laboratory Manual. Ames (IA): Blackwell Publishing Professional; 2006.

15. Bradford MM. A rapid and sensitive method for quantitation of microgram quantities of protein utilizing the principle of protein-dye binding. Analyt Biochem 1976;72:248-54.
16. Laemmli UK. Cleavage of structural proteins during the assembly of the head of bacteriophage T4. Nature 1970;227:680-5.

17. Towbin H, Staehelin T, Gordon J. Electrophoretic transfer of proteins from polyacrylamide gels to nitrocellulose sheets: procedure and some applications. Proc Natl Acad Sci USA 1979;76:4350-4.

18. Howard DH. Pathogenic Fungi in Humans and Animals. 2nd ed. New York (NY): Marcel Dekker; 2003.

19. Sanchez H, Bush RK. A review of Alternaria alternata sensitivity. Rev Iberoam Micol 2001;18:56-9.

20. Zureik M, Neukirch C, Leynaert B, Liard R, Bousquet J, Neukirch F. Sensitisation to airborne moulds and severity of asthma: cross sectional study from European Community Respiratory Health Survey. Br Med J 2002;325:411-4.

21. Vancanneyt M, Lerberg EV, Berny JF, Hennebert GL, Kersters K. The application of whole-cell protein electrophoresis for the classification and identification of basidiomycetous yeast species. Antonie van Leeuwenhoek 1999;61:69-78.

22. Aghamirian MR, Zaini F. Analysis of electrophoretic patterns of extracted somatic proteins from Fusarium solani. J Qazvin Univ Med Sci 2001;4:51-7.

23. Mandeel QA, Gamal El-Din AY, Mohammed SA. Analysis of SDS-dissociated proteins of pathogenic and nonpathogenic Fusarium species. Mycopathologia 1994;127:159-66.

24. Verma J, Gangal SV. Fusarium solani: immunochemical characterization of allergens. Int Arch Allergy Immunol 1994;104:175-83.

25. Burt ET, Oconnor C, Larsen B. Isolation and identification of a $92-\mathrm{kDa}$ stress induced protein from Candida albicans. Mycopathologia 1999;147:13-20.

26. Verma J, Sridhara S, Rai D, Gangal SV. Isolation and immunobiochemical characterization of a major allergen (65 kDa) from Fusarium equiseti. Allergy 1998;53:311-5.

27. Verma J, Sridhara S, Singh BP, Pasha S, Gangal SV, Arora N. Fusarium solani major allergen peptide IV-1 binds IgE but does not release histamine. Clin Exp Allergy 2001;31:9207.

28. Verma J, Singh BP, Sridhara S, Gaur SN, Arora N. Purification and characterization of a cross-reactive $45-\mathrm{kD}$ major allergen of Fusarium solani. Int Arch Allergy Immunol 2003;130:1939.

29. Hoff M, Ballmer-Weber BK, Niggemannc B, Cistero-Bahima A, San Miguel-Moncín M, Conti A, Haustein D, Vieths S. Molecular cloning and immunological characterization of potential allergens from the mould Fusarium culmorum. Mol Immunol 2003;39:965-75.

30. Khosravi AR, Naseri Bandghorai A, Moazzeni M, Shokri H, Mansouri P, Mahmoudi M. Evaluation of Candida albicans allergens reactive with specific IgE in asthma and atopic eczema patients. Mycoses 2008;52:326-33. 
Sažetak

\section{ALERGENI IZ PLIJESNI FUSARIUM SOLANI U IRANSKIH BOLESNIKA S ASTMOM UTVRĐENI S POMOĆU IMUNOBLOT-TESTA}

Ekstrahirali smo antigene plijesni Fusarium solani kako bismo izmjerili imunosni odgovor, tj. razine antiF. solani IgE u 52 bolesnika s astmom (33 muškarca i 18 žena) te u 22 zdrava ispitanika bez atopija (15 muškaraca i sedam žena). Sojevi $F$. solani uzgojeni su na podlozi glukoznoga Sabouraudova agara i podvrgnuti razbijanju stanica s pomoću metode smrzavanja i odmrzavanja. Dobiveni citoplazmatski ekstrakti analizirani su s pomoću elektroforeze u poliakrilamidnom gelu u prisutnosti natrijeva dodecilsulfata (engl. sodium dodecyl sulphate-polyacrylamide gel electrophoresis, krat. SDS-PAGE). Senzibilizacija na antigene $F$. solani u bolesnika s astmom utvrđena je s pomoću imunoblot-testa. S pomoću SDS-PAGE-a u citoplazmatskim ekstraktima izolata $F$. solani dokazano je 29 proteinskih vrpca. Molekulske mase razdvojenih proteina kretale su se u rasponu od $24 \mathrm{kDa}$ do $112 \mathrm{kDa}$. Imunoblot-test otkrio je specifično anti-F. solani IgE- protutijelo u svih bolesnika s astmom, ali niti u jednog ispitanika iz kontrolne skupine. Najčešći su alergeni u bolesnika s astmom odgovarali proteinima ovih molekulskih masa: $24 \mathrm{kDa}, 58,5$ $\mathrm{kDa}, 64,5 \mathrm{kDa}, 69 \mathrm{kDa}, 72 \mathrm{kDa}$ i $97 \mathrm{kDa}$.

Naši nalazi upućuju na to da simptome astme u osjetljivih pojedinaca može izazvati više alergena soja $F$. solani te da ih treba podrobnije istražiti.

KLJUČNE RIJEČI: alergija na plijesni, IgE, SDS-PAGE, senzibilizacija na alergene, spore u zraku

\section{CORRESPONDING AUTHOR:}

Prof. Ali Reza Khosravi, D.V.M, Ph.D, Mycology Research Center, Faculty of Veterinary Medicine. P.O. Box: 14155-6453, Tehran, Iran

E-mail:khosravi@ut.ac.ir 